\title{
Dr. Belisario Calderón
}

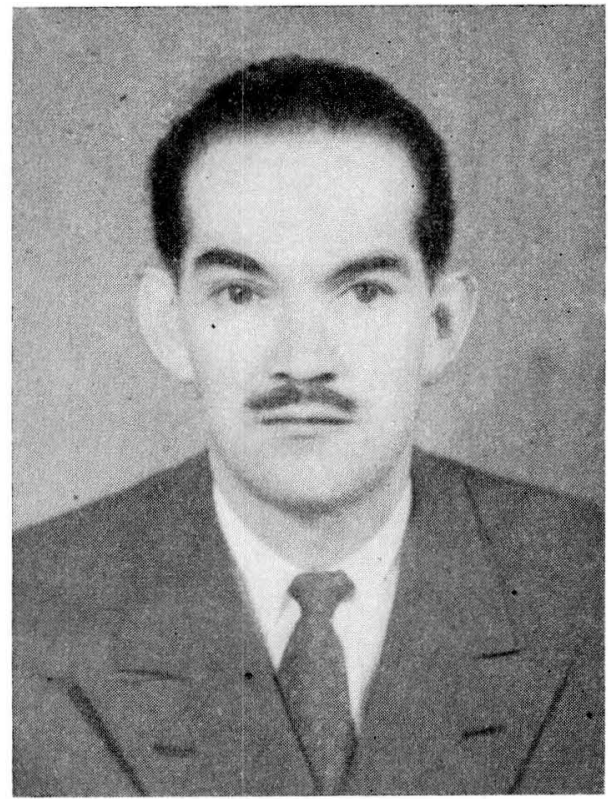

Las páginas de la REVISTA COLOMBIANA DE OBSTETRICIA Y GINECOLOGIA se enlutecen hoy por el fallecimiento del Dr. BELISARIO CALDERON MENENDEZ, brillante figura de la medicina nacional, ocurrido recientemente en la ciudad de Bogotá.

Confundidos aún por tan infausta noticia, apenas sí podemos evocar los razgos salientes de su atrayente personalidad.

Sobresaliente profesional, el Dr. Calderón fué escalando los peldaños del prestigio médico y acrecentando con sus actos la admiración de sus colegas. Su temprana desaparición lo sorprendió en el cenit de su vertiginosa trayectoria por los caminos de la profesión después de recorrerlos sin pausa y con desvelo.

Frutos de su esfuerzo fueron las altas posiciones alcanzadas con el beneplácito de una generación que le juzgó entre los mejores. Su vida, entrañablemente unida al Hospital de San José de Bogotá del cual fué su Director, constituye un ejemplo de abnegación y sacrificio.

A la hora de su muerte desempeñaba la Cátedra de Obstetricia y Ginecología de la Universidad Javeriana y desde allí, más que el profesorado, ejercía la misión nobilísima de los maestros.

Miembro prestante de la Sociedad Colombiana de Obstetricia y Ginecología, sus aportes a ella a través de conferencias y congresos, legado son de valor incalculable. Paradigma de la amistad, del trabajo y la modestia, su nombre será recordado con admiración y afecto.

Estas páginas se honraron varias veces con la publicación de sus trabajos científicos. Sus colaboraciones tenían el sello inconfundible de su clara inteligencia y revelaron el juicio y solidez de sus conocimientos clínicos.

El Cuerpo Médico Colombiano, a cuyo prestigio contribuyó, está de duelo por el fallecimiento del Dr. Belisario Calderón, amigo, científico y maestro. 